\title{
PSYCHOLOGICAL TESTING AND CONSTITUTIONAL RIGHTS
}

\author{
William A. CREEch*
}

The federal government uses psychological tests throughout the employment process-in hiring, promoting, and retiring its employees. Some of these tests probe into the most intimate aspects of an individual's life. Do these tests produce their intended results? Are they necessary for effective government service? Do they unreasonably interfere with the private lives of the individuals tested? These and other questions have been asked with increasing frequency recently, and the author, who was counsel to the Senate Subcommittee which has been investigating governmental psychological testing, attempts to answer some of them in this article.

DSYCHOLOGICAL TESTING of government employees has become widespread in recent years. The use by the federal government of these tests-particularly those which purport to measure and categorize "personality"-poses a unique challenge to both Congress and the courts in their effort to protect individual constitutional rights. How the problems raised by these and other devices are dealt with may be an important indicator of the effectiveness of judicial and legislative control over that complex bureaucracy which is our federal government. Additionally, solutions to these problems may measure the ability of Congress and the courts to cope with the demands which technological advances have placed upon our system of government, upon the very fabric of our cultural life, and upon the concept of individual rights in a democratic society. ${ }^{1}$ To the extent that solutions to these problems are successful will the citizenry be in control of what may be the two greatest forces influencing our lives today-bureaucracy and scientific technology.

The role of the courts in solving these problems has thus far been rather limited. No significant body of case law has as yet been developed, chiefly because psychological testing is a twentieth

* A.B. 1948, University of North Carolina; LL.B. 1958, Georgetown University. Member, North Carolina Bar. Former Chief Counsel and Staff Director, Subcommittee on Constitutional Rights of the Senate Judiciary Committee.

${ }^{2}$ See the brief historical discussion in Freeman, Theory and Practice of PsYchological Testing 1-23 (3d ed. 1962). 
century innovation. The case law which does exist stems primarily from the evolution of the legal concept of a right of privacy. ${ }^{2}$ This developing law suggests that psychological testing as a means of searching the innermost thoughts of man may be an even greater invasion of one's privacy than some of the practices-such as stomach pumping and coerced confessions-which the courts have already held illegal.

The part played by the courts may, however, be considerably expanded in the future. The courts have already entered the field of individual rights in matters relating to the federal loyalty-security program, and the similarities between that area and the Government's unannounced "psychiatric health program" are striking. The procedures utilized in both fields may, to a somewhat similar degree, affect an individual's reputation and his job prospects. A cloud cast upon an individual's emotional stability, his competence, or his personal acceptability to society may have effects almost as far-reaching as suspicion cast upon his loyalty and trustworthiness under a loyalty-security program. Indeed, because of the duplication of the criteria in the two programs, the results may be identical. A medical record containing unassessed information based on psychiatric evaluation and psychological reports from high school and college years may follow a person into government work and jeopardize his chances for a security clearance.

More immediate control of government psychological testing may be effected by Congress, ${ }^{3}$ of course, and what Congress does in this area will have significant repercussions throughout the country. The recent history of the federal personnel security program

\footnotetext{
"The "right to privacy" as a tort is now recognized in more than 30 American jurisdictions. Prosser, TORTs $\S 112$, at 831-32 (3d ed. 1964). See generally Bloustein, Privacy as an Aspect of Human Dignity: An Answer to Dean Prosser, 39 N.Y.U.L. Rev. 962 (1964); Prosser, Privacy, 48 Calif. L. REv. 383 (1960). Privacy was first recognized as an independent constitutional right in Griswold v. Connecticut, 381 U.S. 479 (1965). See Emerson, Nine Justices in Search of a Doctrine, 64 MrcH. L. REv. 219, 229 (1965).

${ }^{3}$ Congressional inquiry has been proceeding apace with investigations of governmental usage of such instrumentalities as the polygraph and wiretap and eavesdropping devices. See, e.g., Hearings on Wiretapping, Eavesdropping, and the Bill of Rights Before the Subcommittee on Constitutional Rights of the Senate Committee on the Judiciary, 86th Cong., Ist \& 2d Sess. (1959-1960), 87th Cong., 1st \& 2d Sess. (1961-1962); Hearings on Invasions of Privacy by Government Agencies Before the Subcommittee on Administrative Practice and Procedure of the Senate Committee on the Judiciary, 89th Cong., 1st Sess. (1965); Hearings on Invasion of Privacy Before a Subcommittee of the House Government Operations Committee, 89th Cong., Ist Sess. (1965).
} 
offers a classic example of the extent to which federal attitudes, policies and practices may be emulated and adopted, sometimes with unfortunate consequences, by private individuals and corporations as well as by local and state governments. If, therefore, Congress should take a firm position with respect to the more obnoxious features of psychological testing, this action can be expected to produce salutary effects beyond the limited area of federal employment practices.

A full evaluation of all the ramifications of psychological testing in our society would be a monumental undertaking. This article will not attempt to examine exhaustively all facets of the problem. Rather, using a recent congressional investigation as a basis, it will concentrate on the current policies and practices in the Government, the arguments pro and con on governmental use of testing, and the constitutional objections which have been raised to the tests. Finally, some alternative solutions to the problem will be indicated.

\section{I}

\section{A Brief History of Psychological Testing}

Research in the behavioral sciences has presented scientific, technical, legal, ethical, and philosophical issues which have been studied for many years. ${ }^{4}$ Private, legal, and medical groups, as well as state legislatures, have sought solutions to the problems involved, but in most cases public law has lagged far behind scientific advances. ${ }^{5}$

Psychology as a science and as a profession has grown in stature since World War I. Its use in armed forces programs during the First World War and in psychiatric diagnosis and treatment of returning war veterans added to its significance as a force in human affairs. Furthermore, acceptance of psychological principles has been accelerated by the many factors attendant on the growth of American society and by the stresses placed upon the individual in an industrialized, urban environment. Hence, one is hardly surprised to find the utilization of psychological testing widely diffused

\footnotetext{
- For a recent attempt to strike a balance between the need for scientific research in the behavioral fields and the "right" of privacy of the individual subjects of that research, see Ruebhausen \& Brim, Privacy and Behavioral Research, 65 CouUn. L. REv. 1184 (1965). The authors contend that an issue of personal privacy arises "if the individual respondent does not participate willingly, or if he participates without knowledge of the information being elicited from him, or without an understanding of the purposes for which such information will be used." Id. at 1197 .

'See generally Louisell, The Psychologist in Today's Legal World, 39 MiNN. L. REv. 235 (1955); id. (pt. 2), 41 MrNN. L. REv. 781 (1957).
} 
throughout large segments of education, industry, and government. ${ }^{8}$

Concurrent with the expansion of our economy and the growth of our Government, there have arisen in both the private and the public sectors of our society giant bureaucracies which allegedly require for their smooth operation employees who possess certain personality characteristics. This has led to the cult of the "organization man," an individual much examined by sociologists and others. ${ }^{7}$ From an early preoccupation with such matters as organization, work product, and efficiency, the science of "organization theory" has turned recently to the study of the behavior of the individual in organizations and his interpersonal relationship with his fellow workers. In many instances "personality" has become more important as an employment criterion than other qualifications, including the ability to perform the required task.

For these reasons, psychological testing as a quick means of measuring personality attributes has gained wide acceptance in private industry, schools, universities, churches, and all levels of government-local, state, and federal. ${ }^{8}$ Those subjected to personality "inventories" for research purposes as well as for personal assessment include "medical students, ministers, policemen, librarians, candidates for the priesthood, parents of disturbed children, salesmen, law students, psychiatric aides, medical and psychiatric patients, psychology trainees, military personnel, ninth grade school children, retired oldsters, professional ball players, veterans, prisoners and astronauts."'?

\footnotetext{
${ }^{\circ}$ See Freenan, op. cit. supra note 1, at 12-21.

7 The most widely known lay treatment is probably Whyte, The Organization MAN (1956).

${ }^{8}$ See FreEMran, op. cit. supra note 1, at 19-21.

- Hearings on Rights of Government Employees, Psychiatric Exams and Psychological Tests Before the Subcommittee on Constitutional Rights of the Senate Committee on the Judiciary, Transcript, 89th Cong., 1st Sess. 568 (1965) [hereinafter cited as Hearings Transcript] (testimony of Dr. W. Grant Dahlstrom, Professor, University of North Carolina).

The proliferation of tests and test situations has been decried by those without and within the psychological profession. As an example of the latter, see VERNON, PERSONALITy Assessment: A CRItical SuRvey 267 (1964):

"Unfortunately the test [the Minnesota Multiphasic Personality Inventory, one of the most widely used of the personality tests] is also widely used in the United States as a general screening device for teachers and other job applicants, and this is to be deplored. It is most unlikely that score patterns have the same significance under these conditions as they do in a mental hospital, and there is no evidence that psychologists can reliably pick out individuals with 'unsuitable' personalities by means of it."
} 
The federal government has included psychological considerations in many of its programs and staffing operations and annually spends large sums for psychological research. Never before in our history has the Government been so concerned with the personalities of its citizens. Of particular interest is the employment of large numbers of psychiatrists and psychologists on a full time, part time, or contract basis for the purpose of assessing the mental health and personalities of the federal government's two and a half million employees. One agency, for example, spends from $\$ 51$ to $\$ 150$ each for the testing of applicants and candidates for key managerial positions. ${ }^{10}$ The expanding use of such testing is indicated by the growing importance of psychiatric and psychological considerations in routine personnel decisions regarding "suitability" of federal employees.

As a result of resent sensitizing of citizens to their rights of privacy and to fair play from the Government, ${ }^{11}$ members of Congress have received an increasing number of complaints about the types of questions being asked of applicants and employees being considered for promotion, transfer, or dismissal by the federal government. Partially in response to these complaints, the Constitutional Rights Subcommittee of the Senate Judiciary Committee has conducted an extensive study of the entire field of government psychological testing. The work of the Subcommittee provides an illuminating case study for lawyers on the role of Congress in the protection of constitutional rights of individuals. Furthermore, it demonstrates how public policy can be changed or defined as a result of a few complaints registered in the proper places in an effective, timely fashion.

\section{II}

\section{The Role of Congress: Investigation by the Subcommitee}

\section{A. Scope of the Subcommittee Inquiry}

In the course of investigating the rights of federal employees, the Constitutional Rights Subcommittee over a two-year period received and investigated numerous complaints that federal employees

\footnotetext{
${ }^{10}$ Hearings Transcript.

${ }^{11}$ Contributing to this sensitizing process have been such popular works as DASH \& KNowlton, The Eavesdroppers (1959) and Packard, The NAKEd Society (1964). In addition, the various congressional investigations (see note 3 supra) have not been without their effect.
} 
were being subjected to mind-probing sessions with government psychiatrists and psychologists in general screening programs-such as that used by the Peace Corps-or for hiring, firing, and promotion purposes. ${ }^{12}$ The investigation shows that supervisors may suggest or require "fitness for duty examinations" which may include psychological testing, under subtle threats of disciplinary action for insubordination or loss of a job. The charge has been made that some of the questions contained in the personality inventories relating to sex, religion, and many personal aspects of the employee's life constitute an unjustified invasion of privacy. ${ }^{13}$ Furthermore,

${ }^{10}$ An employee classified as "emotionally disturbed" or "mentally disabled" under one set of regulations (for example, for purposes of retirement) may be deemed a "security risk" for other purposes (such as access to classified information) under other regulations.

The connection between psychological testing and the loyalty-security program can be seen by consulting Security Requirements for Government Employees, Exec. Order No. 10450, 18 Fed. Reg. 2489 (1953), as amended, Exec. Order No. 10491, 18 Fed. Reg. 6583 (1953), Exec. Order No. 10531, 19 Fed. Reg. 3069 (1954), Exec. Order No. 10548, 19 Fed. Reg. 4871 (1954), Exec. Order No. 10550, 19 Fed. Reg. 4981 (1954). Agency heads are authorized to terminate summarily the employment of an employee "in the interests of the national security" if an investigation warrants this action. Section 8 of this order, as amended, provides as follows:

"SEC. 8. (a) The investigations conducted pursuant to this order shall be designed to develop information as to whether the employment or retention in employment in the Federal service of the person being investigated is clearly consistent with the interests of the national security. Such information shall relate, but shall not be limited, to the following:

"(l) Depending on the relation of the Government employment to the national security:

....

"(iv) Any illness, including any mental condition, of a nature which in the opinion of competent medical authority may cause significant defect in the judgment or reJiability of the employees, with due regard to the transient or continuing effect of the illness and the medical findings in such case."

In fact, this particular provision was most frequently cited by agency representatives before the Subcommittee as authority for the use of psychological tests. S. REP. No. 501, 89th Cong., Ist Sess. 22 (1965).

${ }^{13}$ In a letter to Secretary of State Dean Rusk, Senator Sam J. Ervin, Jr. described a case reported to the Subcommittee and commented:

"This case illustrates a number of undesirable tendencies in Government agencies today; one is the penalizing of the prospective employee whose parents may have taken advantage of the counseling services of psychologists and psychiatrists to assist in resolving the usual problems of their teenage children. These records may then be part of the young person's security investigation in later years, and the very fact that such a visit is part of the person's medical history, apparently, might cause a personnel or security officer to suggest a psychiatric examination and psychological testing. ....

"Complaints received by this Subcommittee suggest that such information obtained in the course of security interviews and investigations tends to acquire a confidential medical status in personnel files, and, interpreted arbitrarily and summarily, can cause irreparable harm to the individual." 111 Cong. Rec. 25038 (daily ed. Oct. 5, 1965). 
the Subcommittee received allegations that, aside from the invasion of privacy, the procedures surrounding the testing, the composition of the tests themselves, and the use made of the test results present serious due process questions. Competent experts in the field have questioned whether the tests being used by government psychologists are reasonable devices for carrying out the mandates of Congress in the personnel field.

As a result of these complaints, the Subcommittee in 1964 initiated an agency-by-agency survey to determine to what extent psychiatric screening and psychological testing was being used and by what authority. Preliminary results of that survey revealed a lack of uniformity of procedures and vague criteria for administering such tests. ${ }^{14}$ Questions also arose regarding the legal authority under which the agencies are operating in these matters. ${ }^{15}$

In a further effort to ascertain whether or not the various charges concerning psychological testing were true, the Subcommittee called an expert panel of witnesses from the legal, medical, psychiatric, and psychological fields to discuss not only the procedures involved but also the psychological tests themselves. The tone of these hearings was set by Subcommittee Chairman Sam J. Ervin, Jr. in his opening statement:

There are some who believe that a federal employee has few rights. For the most part, the rights of the American civil servants have depended upon the generosity of Congress, the President, and upon the courts, which have been slow to define this area of the law. However, I believe that just because he goes to work for the government, the civil servant does not surrender his basic constitutional rights as a citizen; he, as any other citizen, has a right to expect fair play at the hands of his government. ${ }^{16}$

\section{B. Alleged Authority to Test}

It has been suggested that psychological testing and the procedures under which such tests are administered violate the concept of the merit system, and may be used to circumvent the procedural guarantees established by Congress in the basic civil service laws as interpreted by the courts. Nevertheless, as authority for

\footnotetext{
${ }^{14}$ S. REP. No. 501, 89th Cong., 1st Sess. 20-23 (1965).

${ }^{15}$ Many agencies cited Exec. Order No. 10450, 18 Fed. Reg. 2489 (1953), pertaining to the loyalty-security program, as authority for the utilization of psychological testing. See S. REP. No. 501, 89th Cong., 1st Sess. 22 (1965).

${ }^{16}$ Hearings Transcript 4.
} 
their procedure concerning mental fitness exams and personality testing, government officials cite executive orders and civil service laws recognizing presidential authority over selection procedures.

The President has both a constitutional and a statutory power over the selection of civil servants. His constitutional power was defined by Chief Justice Taft in 1926 as follows:

... Article II [of the Constitution] grants to the President the executive power of the Government, i.e., the general administrative control of those executing the laws, including the power of appointment and removal of executive officers-a conclusion confirmed by his obligation to take care that the laws be faithfully executed . . . . ${ }^{17}$

The President is also granted statutory authority to regnlate admissions to the civil service, and under this general power, he may

prescribe such regulations ... as may best promote the efficiency thereof, and ascertain the fitness of each candidate in respect to age, health, character, knowledge, and ability for the branch of service into which he [the applicant] seeks to enter; and for this purpose he may employ suitable persons to conduct such inquiries, and may prescribe their duties .... ${ }^{18}$

To assist the Chief Executive with the administration of the civil service laws, Congress has established the Civil Service Commission. Because means of selection for federal employment must be practical and fair, ${ }^{19}$ it is the duty of the Commission to prepare rules for open, competitive examinations which "shall be practical in their character, and so far as may be shall relate to those matters which shall fairly test the relative capacity and fitness of the persons examined to discharge the duties of the service into which they seek to be appointed."20

Within this framework, the President has issued executive orders setting broad policy and procedural guidelines to be adopted and implemented by the Commission and adapted by departments and agencies to suit their particular needs. By executive order the Commission is authorized to carry out the statutory mandate for setting practical, fair examinations and "to establish standards

\footnotetext{
${ }^{17}$ Myers v. United States, 272 U.S. 52, 163-64 (1926).

18 REv. STAT. $\$ 1753$ (1875), 5 U.S.C. $\$ 631$ (1964).

${ }^{10}$ See Civil Service Act $\S 2,22$ Stat. 403 (1883), as amended, 5 U.S.C. $\S 633$ (1964); Exec. Order No. 10577, § 2.1, 19 Fed. Reg. 7521 (1954).

${ }^{20}$ Civil Service Act $\S 2(2), 22$ Stat. 403 (1883), as amended, 5 U.S.C. $\S 633$ (2) (1964).
} 
with respect to citizenship, age, education, training and experience, suitability and physical and mental fitness . . .."21

Pursuant to this executive order and to statute, the Commission has adopted rules establishing standards governing "suitability" of federal employees throughout the Government. They provide that the Commission may deny an applicant examination, deny appointment to an "eligible," and instruct an agency to remove an appointee for any of the following reasons: duct;

"(a) Dismissal from employment for delinquency or miscon-

(b) Criminal, infamous, dishonest, immoral, or notoriously disgraceful conduct;

(c) Intentional false statements or deception or fraud in examination or appointment;

(d) Refusal to furnish testimony as required by $\S 5.3$ of this chapter [relating to information requested pursuant to the laws, rules, and regulations administered by the Commission];

(e) Habitual use of intoxicating beverages to excess;

(f) Reasonable doubt as to the loyalty of the person involved to the Government of the United States, or;

(g) Any legal or other disqualification which makes the individual unfit for service."22

The Commission has delegated to agencies the power to determine that individuals meet the physical and mental requirements for employment in competitive positions but has reserved to itself the final authority to determine that individuals fail to meet such requirements. ${ }^{23}$

As opposed to the regulations governing employment qualifications, the statutes governing the rights of civil servants are few and broadly worded. Generally, they are directed toward assuring that government employees are not subjected to arbitrary and capricious personnel actions. In the Lloyd-LaFollette Act, Congress stipulated that an employee in the classified civil service may be removed or suspended only "for such cause as will promote the efficiency of such service and for reasons given in writing." ${ }^{24}$ It may be noted that while an employee has a statutory right to notice of charges against him, an opportunity to answer such charges personally or

21 Exec. Order No. 10577, 19 Fed. Reg. 7522 (1954). (Emphasis added.)

${ }^{22}$ Suitability Disqualifications, 5 C.F.R. $\$ 731.201$ (1964, Supp. 1965).

${ }^{23}$ Eligibility Standards, 5 C.F.R. $\$ 302.202$ (1964); Qualification Requirements (Medical), 5 C.F.R. $\S 339.101$ (1964); Suitability Rating Actions, 5 C.F.R. $\S 731.301$ (1964, Supp. 1965).

${ }^{24}$ Section 6 (a), 62 Stat. 355 (1948), 5 U.S.C. § 652(a) (1964). 
in writing, and the possibility of appeal to the Civil Service Commission, ${ }^{25}$ he has no statutory right to a hearing with confrontation and cross-examination of witnesses. ${ }^{26}$ This deficiency has been partially corrected by an executive order and subsequent Commission regulations providing for administrative appeals. ${ }^{27}$

However, superimposed upon this system of routine requirements of physical and mental fitness-with administrative hearings prior to action adverse to the employee-is the federal loyaltysecurity program. In this regard, the Act of August 26, 1950, gave agency and department heads "absolute discretion ... in the interest of national security"28 to suspend and after "such investigation and review ... [as is deemed] necessary"29 to terminate the employment of any civilian officer or employee. Pursuant to this statute Executive Order 10450 was issued, requiring investigations to determine whether employment or retention of a person in the federal service "is clearly consistent with the interest of the national security." 30 The information to be gathered by these investigations is to deal with various aspects of a person's life and activities, including any mental condition which might adversely affect his judgment or reliability. ${ }^{31}$

Thus, the question of mental and emotional fitness may arise either during the routine hiring process or in the course of a security

${ }^{25}$ Lloyd-LaFollette Act $\S 6$ (a), 62 Stat. 355 (1948), 5 U.S.C. $\$ 652$ (a) (1964). See also Veterans' Preference Act of 1944, $\S 14,58$ Stat. 390, as amended, 5 U.S.C. $\S 863$ (1964).

20 "No examination of witnesses nor any trial or hearing shall be required except in the discretion of the officer or employee directing the removal or suspension ...." Lloyd-LaFollette Act, $\S 6$ (a), 62 Stat. 355 (1948), 5 U.S.C. $\S 652$ (a) (1964). It has been suggested that the failure to provide for a hearing and confrontation and crossexamination of witnesses when a government employee is discharged for cause is an unconstitutional deprivation of due process of law. Krasnowiecki, Confrontation by Witnesses in Government Employee Security Proceedings, 33 Notre Dame Law. 180, 182-84 (1958); Richardson, Problems in the Removal of Federal Civil Servants, 54 Mich. L. Rev. 219 (1955). But see Kaplan, The Law of Civil Service 230 (1958).

${ }^{27}$ Exec. Order No. 10987, 27 Fed. Reg. 550 (1962) requires the establishment of administrative review procedures within the various departments or agencies subject to regulations of the Civil Service Commission. Those regulations are found in 5 C.F.R. $\S \S 771.201-.228$ (Supp. 1965). A right to a hearing is granted (\$ 771.213) before an impartial committee ( $\S 771.214$ ). Parties have the opportunity to cross-examine witnesses $(\S 771.215(f))$. However, the agency is required to make its employees available before a hearing committee only if it is "administratively practicable" ( $\$$ 771.216 (a)). A few agencies are not covered by the appeals system, including the CIA, FBI, National Security Agency, Atomic Energy Commission, and Tennessee Valley Authority (\$ $771.203(\mathrm{~b}))$.

${ }^{28} 64$ Stat. 476 (1950), as amended, 5 U.S.C. $\$ 22-1$ (1964).

${ }^{20}$ Ibid.

${ }^{30}$ Exec. Order No. 10450, 18 Fed. Reg. 2489 (1953).

sx See text of Exec. Order No. 10450 in note 12 supra. 
investigation. ${ }^{32}$ Under existing procedures the Commission requires a report of medical examination for most appointments in the competitive service-original appointments as well as reinstatementsand for certain other personnel actions. ${ }^{33}$ "When a medical report is not required by the Commission the appointing officer may, in his discretion, obtain one, and he must take appropriate action to resolve any questions of physical fitness which arise or which are brought to his attention during the preliminary selection and appointing process." 34

If certain conditions are noted on the medical certificatesuch as diabetes, organic heart disease, history of mental and nervous disorders, epilepsy or fainting spells-the appointing officer must obtain the opinion of a federal medical officer. ${ }^{35}$ It is sometimes at this stage that psychiatric evaluation or personality testing may be suggested.

\section{G. Current Practices and Uses of Tests}

1. The Need for Testing

In defense of governmental use of psychological tests, officials argue that testing is necessary, effective, and constitutes no real

32 Executive Order 10450 was intended to apply to each department and agency of the Government and to the employment and retention of every civilian officer or employee therein. See Exec. Order No. 10450, § 2, 18 Fed. Reg. 2489 (1953). However, in Cole v. Young, 351 U.S. 536 (1956), the Supreme Court attempted to narrow the impact of the summary procedures prescribed by this executive order by restricting it to positions affecting "national security." The latter term was to com. prehend "only those activities of the Government that are directly concerned with the protection of the Nation from internal subversion or foreign aggression, and not those which contribute to the strength of the Nation only through their impact on the general welfare." 351 U.S. at 544. A Subcommittee survey shows that for purposes of psychiatric evaluations the various agencies are not in agreement about the application of Executive Order 10450. See S. REP. No. 501, 89th Cong., 1st Sess. 12, 20-23 (1965).

${ }^{83}$ An admission on the standard government employment form that an applicant has at some time undergone psychoanalysis or has had an emotional disturbance which required treatment may prompt an agency to require a psychiatric examina. tion before appointment. Question 29 of the form reads "Have you ever had a nervous breakdown?" Many feel that, in an age when more and more people are turning to psychiatrists and psychologists for assistance with personal problems, the fact that a person may have had psychotherapy should not call for an affirmative answer to this question if during that same time he was able to carry on the normal routine of life and earn a livelihood. Yet some federal personnel officials have taken the position that under these circumstances a person should answer question 29 in the affirmative, which may lead to his being rejected for government employment. S. REP. No. 501, 89th Cong., 1st Sess. 20 (1965).

34 U.S. Givil Service Comm'n, Federal Personnel Manual 399.9 (1963).

${ }^{35}$ Id. at 339-10. 
invasion of privacy. Civil Service Commission Chairman John Macy testified that the Government is thereby able to screen its work force to disqualify individuals with "demonstrable emotional or behavioral disorders that would ... create a hazard both to the government and to the employee." ${ }^{36}$

According to a representative of the State Department, "psychiatric evaluations and psychological testing are two necessary and effective means of . . a assuring that its employees are fit for employment from both the medical and security standpoints." 37 The Department considers virtually every one of its positions both in Washington and overseas to be a sensitive job, requiring access to classified information. The purpose of testing employees and their dependents is to determine the individual's psychological and emotional state,

to detect organic brain disturbances, to ascertain whether any previous psychotherapy has reached its maximum effectiveness and further treatment is no longer indicated, to provide guidance to personnel officers in choosing position assignments, and to assist in determination of the presence of impaired judgment or reliability in reference to Executive Order 10450.38

The Department representative told the Subcommittee that "most of this nation's security problems have resulted from emotional and moral disturbances and problems ....."39

Government administrators were in agreement in their faith that the tests do what they are supposed to do. They all referred to their dependence on the "experts," the "preponderance of the evidence," "professional acceptance" of the tests, ${ }^{40}$ and scientific research supporting testing.11

When it was pointed out that one State Department employee who was tested was given performance reports attesting to her emotional stability, adjustment, and capability to work rapidly and efficiently under pressure, the Department administrator replied that this was why he was not sure there should be efficiency reports.

\footnotetext{
${ }^{30}$ Hearings Transcript 425 (statement of John W. Macy, Jr., Chairman, Civil Service Commission).

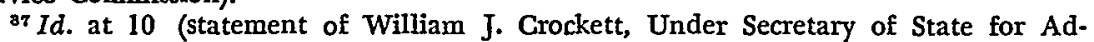
ministration).

${ }^{38} \mathrm{Id}$. at 12 (statement of $\mathrm{Mr}$. Crockett). See note 12 supra.

so Hearings Transcript 23 (testimony of $\mathrm{Mr}$. Crockett).

to E.g., id. at 70 (testimony of Mr. Crockett).

1 See, e.g., id. at 135-38 (statement of Dr. Arthur H. Brayfield, Executive Director, American Psychological Ass'n).
} 
He deplored the fact that none of the Department's supervisors are psychiatrists, psychologists or doctors. $\mathrm{He}$ was uncertain whether "any of them would recognize any but the most flagrant cases of emotional instability." 42

\section{Testing Procedures}

The State Department representative described existing procedures under which employees of the Department and twelve other agencies are examined. In each instance the medical staff determines whether an individual should have a psychiatric evaluation or undergo psychological testing, or both. These steps are taken whenever a staff physician believes an employee may have an emotional or psychological problem which would require treatment or impair his judgment and reliability or be aggravated by an overseas assignment. If the employee agrees to a psychiatric examination, he is given a choice of one of the Department's four consulting psychiatrists. If the psychiatrist decides that psychological testing would be of assistance, he explains to the employee the need for it. The employee is then referred to a consulting psychologist who performs the testing in his private office and sends the psychiatrist a summary report of his findings. After the psychiatrist has reviewed this report, he discusses it with the employee and submits his own report to the medical division of the Department. The staff physician then makes a final determination about the existence of a problem and submits his own evaluation to the Department as to the individual's employability, restrictions which should be placed on his assignments, or his eligibility for retirement. ${ }^{43}$

There are a number of objections that can be made to this procedure. First, neither the employee nor the administrator at the policy level knows what has caused a certain evaluationwhether it was a failure to answer or responding in a particular manner. ${ }^{44}$ The type of problem is not identified, and the mystery surrounding an employee's rejection, dismissal, or retirement may cause him employment difficulties later. He cannot refute a report he cannot read.

Second, any information that may have come to the Depart-

12 Id. at 26 (testimony of Mr. Crockett).

${ }^{ \pm 3} \mathrm{Id}$. at 11-12 (statement of Mr. Crockett).

«Id. at $37-39$ (testimony of Dr. Lewis Woodward, Medical Director, Dep't of State). This witness stated, however, that he had never known of a case where an employee had refused to answer any questions at all. 
ment from a security investigation, from personnel directors, from supervisors, or from the examining physician is included in the information given to the psychologist and psychiatrist for use in making an evaluation. ${ }^{45}$ The employee has little chance to present his own explanation of circumstances which might have surrounded any particular incident. ${ }^{46}$

Third, the psychiatric report based on the testing is placed in a special file in a separate cabinet apart from the general medical file. The report is not made available to the individual although it is discussed with him and may be sent to his own physician if he so requests. 47

Fourth, the Department admits to using seven different psychological tests similar in nature to the Minnesota Multiphasic Personality Inventory, although use of the MMPI has been discontinued. ${ }^{48}$

\section{Agency Control of Testing}

There is evidently a general disclaimer of responsibility by the agencies for fairness and effectiveness of methods utilized in medical and psychiatric evaluations and for the adequacy of qualifications of personnel involved. ${ }^{49}$ This is probably the primary reason for the lack of uniformity of standards and procedures among agencies, and for variations in the way different cases are handled in one department. The Peace Corps, for example, makes no effort to restrict either psychologists or psychiatrists by spelling out precisely what they can or cannot do. In fact, a spokesman indicated that if it attempted to do this, qualified psychologists would refuse to work for the Peace Corps..$^{50}$ In this same connection, a State Department representative commented:

Certainly there is no standard formula. If the psychologist determines, on the basis of the need in a particular instance in his appraisal of the preliminary review with the patient, how many and which type of tests are employed, we do not indicate procedures to be followed. If the psychologist will make that determination, he will, completely, and we will not necessarily know which tests have been employed.51

\footnotetext{
"Id. at 42-43 (testimony of Dr. Woodward).

${ }^{6}$ Id. at 43 (testimony of Dr. Woodward).

"Id. at 34 (testimony of Dr. Woodward).

${ }^{8}$ Id. at 21 (testimony of Dr. Woodward).

"See, e.g., id. at 51 (testimony of Dr. Woodward), 70 (testimony of Mr. Crockett).

${ }^{50} \mathrm{Id}$. at 315 (testimony of Dr. Al Carp, Director, Selection Div., Peace Corps).

${ }^{-1} I d$. at -.
} 
The Civil Service Commission feels that the task of identifying persons with mental disorders is properly a matter for the judgment of competent medical specialists. Furthermore, the specific diagnostic methods used in psychiatric evaluations are left to the discretion of medical experts. ${ }^{52}$

\section{Agency Uses of Testing}

Psychological tests are given by the various agencies of the Government for a wide variety of purposes. The Peace Corps, for example, makes use of the MMPI and other personality tests as an integral part of the selection process. It considers the MMPI the "only objective personality inventory which helps identify persons who may have or develop serious personality disorders." ${ }^{3}$ The Peace Corps believes there is no acceptable alternative and that if this test were not used, "more volunteers sent overseas would fail to complete their ... service for psychiatric reasons," ${ }^{54}$ and would thus harm the interest of the United States, the Peace Corps, and the volunteer himself.

The tests are administered to trainees as a group under the direcof a psychologist, ${ }^{55}$ a practice criticized because the necessary rapport with the individual is lost, as is the medical setting recommended for testing. Peace Corps psychologists claim if the individual MMPI profile indicates a deviate, he is interviewed more closely by the psychologist and the psychiatrist, and the selection becomes a highly individualized process. ${ }^{56}$

In the Job Corps, tests are used to identify a serious degree of mental retardation and to provide information about a particular age group. Here, the tests are information-gathering devices, rather than selection tools. VISTA selection procedures, on the other hand, include a type of testing oriented to a sociological rather than psychological point of view. ${ }^{57}$

The Air Force uses a form which questions personality traits for purposes of measuring a person's ability to work effectively

\footnotetext{
${ }^{52}$ See id. at 329-30 (testimony of Sargent Shriver, Director, Peace Corps), 428 (statement of Mr. Macy), 481 (testimony of James C. O'Brien, Director, Personnel Mgmt. Div., Dep't of Health, Education and Welfare).

${ }^{53}$ Id. at 307 (statement of Dr. Carp).

84 Id. at 308 (statement of Dr. Carp).

${ }^{55}$ See id. at 312-13 (testimony of Dr. Carp).

${ }^{5 B} I d$. at 320 (testimony of Dr. Carp).

${ }^{8 z}$ See $i d$. at 352 (testimony of Dr. Otis A. Singletary, Director, Job Corps).
} 
with foreign personnel.58 The Subcommittee was told that psychiatric evaluations may be made of military personnel where doubt exists as to fitness for continuing on duty when competent medical personnel believe that such action is required in the interests of the service. For example, under the Department of Defense "human reliability" program, when it appears to a commander and to a medical officer that an individual working with nuclear weapons displays significant signs of a mental or emotional disorder, the individual may be required to undergo a clinical evaluation. A Defense Department representative commented: "These evaluations are conducted by competent military psychiatrists under strict clinical conditions. Based upon the evaluation and other pertinent facts the individual may be reassigned to other duties, reassigned for treatment, or discharged from the Service for medical reasons."'50

Personality testing has been used in the Department of Health, Education and Welfare with various groups for research purposes to determine test reliability, validity, and relevance to particular situations. Tests were formerly used for promotion purposes by the Social Security Administration and still are used by that group for measuring the relationship between performance on the test and in public contact work of certain jobs. Other studies are underway for research purposes. ${ }^{60}$

\section{Examples of the Use of Testing}

Many instances and alleged abuses of the use of personality tests were brought to the attention of the Subcommittee, involving both testing for sensitive positions, such as those in the intelligence agencies, and nonsensitive situations. The following examples are illustrative.

A young college graduate applying for a position with the $\mathrm{Na}$ tional Security Agency was asked to take a personality test which probed her thinking on sex, religion, family, and other personal matters. $^{61}$ Young people applying for jobs as youth counselors were asked by the Labor Department whether they believed in God, liked poetry, and ever became "excited or thrilled." 62 In one case, a

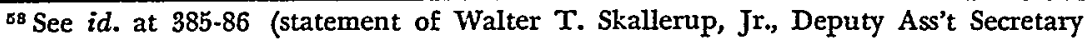
of Defense).

${ }^{50} \mathrm{Id}$. at 388 (statement of Mr. Skallerup).

${ }^{\circ}$ See id. at 460-62 (statement of Mr. O'Brien).

${ }^{21}$ See S. REP. No. 501, 89th Cong., Ist Sess. 20 (1965).

as Ibid.
} 
secretary who had broken her hip was confronted with psychological tests by a government psychologist as she lay under sedation in the hospital. $^{63}$ In another typical case, a secretary employed by the State Department was asked to take a battery of personality tests when she applied for reassignment overseas. Her request for reassignment was based on the grounds that she displayed a weight loss and shortness of breath at the end of her prior assignment in Venezuela. ${ }^{64}$ Her civil ratings and recommendations were glowing tributes to her past performances, her capability, and her potential usefulness to the Department. ${ }^{65}$ Nevertheless, she was subjected to an extensive test on matters relating to her family, sex life, religion, and personal habits. One phase of the test involved 570 questions to which she was to respond "quickly and without any thinking or deliberation." ${ }^{66}$ Included were such true-false questions as the following:

Christ performed miracles.

I believe there is a devil and hell in after life.

Once in a while I think of things too bad to talk about.

I believe in a life hereafter.

I feel sure there is only one true religion.

Many of my dreams are about sex matters.

I pray several times a week. ${ }^{67}$

She had to indicate whether she was troubled, and to what extent, by matters including:

Deciding whether I'm really in love.

Being too inhibited in sex matters.

${ }^{63}$ See Hearings Transcript 67, 467-70.

(see id. at 24 (testimony of Mr. Crockett).

${ }^{65}$ See $i d$. at 25 (testimony of $\mathrm{Mr}$. Crockett).

${ }^{86}$ See $i d$. at 60 .

er Ibid.

The testers manifest a certain obsession with matters pertaining to sex and religion. With respect to the latter item, at least, it is arguable that such inquiries violate Civil Service rules:

"No person employed in the executive branch of the Federal Government who has authority to take or recommend any personnel action with respect to any person who is an employee in the competitive service or any eligible or applicant for a position in the competitive service shall make any inquiry concerning the race, political affiliation, or religious beliefs of any such employee, eligible, or applicant." 5 C.F.R. $\S 4.2$ (1964). (Emphasis added.)

Cf. Vitarelli v. Seaton, 359 U.S. $535,542-44$ \& n.5 (1959). 
Confused in my religious beliefs.

Differing from my family in religious beliefs. ${ }^{88}$

She was given 225 questions consisting of "pairs of statements about things that you may or may not like," and directed to "choose the one that is more applicable to you. If you like both, choose one you like best. If you like neither choose one you like least." Included were the following choices:

A. I feel depressed by my own inability to handle various situations.

B. I like to read books and plays in which sex plays a major part.

A. I feel like blaming others when things go wrong for me.

B. I feel I am inferior in most respects.

A. I like to listen to or tell jokes in which sex plays a major part.

B. I feel like getting revenge when someone has insulted me.69

This employee answered some of the questions, but refused to respond to others on the ground that they had nothing to do with her ability to do her job. When the medical division of the Department refused to grant a medical clearance, she could not receive an unqualified authorization for reassignment. ${ }^{70}$ When this case was publicized, the Subcommittee received numerous letters and telephone calls from present or former Foreign Service officers, State Department employees, and members of their families who reported similar experiences.

It is possible for an agency to utilize the medical fitness procedures to oust an unpleasant but efficient employee or one who has proved politically embarrassing or overly critical of policy and procedures. Although it is difficult to prove, the charge has been made that procedures governing separations and adverse personnel actions may thereby be avoided. ${ }^{71}$

In one complaint, an employee who disagreed with her supervisor and colleagues was asked to submit to a "fitness for duty examination" which involved psychiatric interviews and then psychological testing. ${ }^{72}$ Another case involved an applicant for a federal job who was asked to undergo psychological testing partly because,

\footnotetext{
${ }^{68}$ See Hearings Transcript 46.

${ }^{\circ 0}$ See id. at $48-49$.

${ }^{70}$ See id. at 24-25 (testimony of Mr. Crockett).

${ }^{71}$ See id. at 483-91 (testimony of Michael Urgo, former civilian employee, Dep't of the Navy).

${ }^{72}$ See id. at -
} 
in the course of a security investigation, his former employer, with whom he had disagreed on a professional matter, mentioned to an investigator that he had a personality problem and was disliked by some of his fellow workers. Yet he had an excellent professional record and contrary reports regarding his personality were offered by a number of his colleagues. ${ }^{73}$

Numerous complaints came from employees who, after submitting to examination, either were asked to submit a request for medical disability retirement or were retired involuntarily by the agency on the basis of psychiatric evaluations. The gravity of individual rights in this area is illustrated by the sheer number of employees affected. A seven-year analysis of disability retirement of federal employees from July 1, 1955, to June 30,1962, shows that 100,865 civilian government employees were accorded disability retirement. Of this number, 13,300 were recorded as retired for "nervous system" diseases. Of these, over 9,000 were reported for either "psychoneuroses" (6,271), "schizophrenia" $(2,293)$, "manic depressive psychoses" (298), "paranoia" (101), or "psychoses undetermined" $(68) \cdot{ }^{74}$

Other employees may voluntarily submit a request for disability retirement for physical ailments and be submitted to psychological testing, in lieu of or in addition to a physical examination. $^{75}$ For instance, an employee who had been hospitalized several times over a two-year period for a heart condition requested a disability retirement. He was called for a physical examination, but when he reported for it, the personnel officer told him it was to be a psychological examination. He was then asked what caused him to "imagine" he was having heart attacks and was subjected to extensive psychological testing about such matters as his sex life, loving his mother, hating his father, believing in God, and whether or not he would like to be a florist. ${ }^{76}$

\section{E. The Case for the Tests}

Aside from government officials, ${ }^{77}$ psychological testing was most vigorously defended by the American Psychological Association,

\footnotetext{
${ }^{73}$ See id. at - .

${ }^{71}$ Tish, Prevalence of Disabilities Among Government Employees, $6 \mathrm{~J}$. OccupatronaL MEdicine 9-12 (1964).

${ }^{75}$ See Hearings Transcript 438-39 (testimony of Mr. Macy).

${ }^{70}$ See id. at 614-17 (statement of John F. Griner, President, American Federation of Gov't Employees).

${ }^{77}$ See notes $36-42$ supra and accompanying text.
} 
whose membership of 24,500. includes most of the qualified psychologists in the United States. Association representatives claimed that such testing endangers no rights but rather that "no other professional tool . . . has matched the effectiveness of psychological tests in assisting individuals to realize their civil and human rights . . . "78

Nevertheless, the Association cautioned that where tests are used in personnel decisions, two conditions must be observed: (I) the tests must be supervised in most instances by a qualified psychologist and (2) the test data must constitute only one source of evaluative data. ${ }^{79}$ Given these conditions, the Association argued that the tests can be used to identify the potentially most effective members of an occupational group and to indicate persons suitable to perform in a given situation when analysis of the job demonstrates that it requires certain unique personality characteristics or behavioral patterns. ${ }^{80}$ Use in each of these circumstances, however, presupposes professional judgment regarding the tests and the particular job requirements.

Psychologists, as well as psychiatrists, argue that the tests are

\footnotetext{
${ }^{78}$ Hearings Transcript 130 (statement of Dr. Arthur H. Brayfield). In eludicating this point, Dr. Brayfield argued:

"Undoubtedly the most rewarding application of psychological testing has been its very great utility in the discovery, of unrecognized talent and under-developed personal resources. Tests have helped to identify the potentialities and unique personal qualities of the 'sleepers,' the overlooked or neglected, and people in general.

"The use of tests also ... has demonstrated that many arbitrary barriers to employment such as age, sex, religion, race, and education requirements are responsible for a great waste of human resources.

"In many areas tests open to all have produced more democratic judgments for the greatest good of the greatest number." Id. at 129-30. (Emphasis in original.)

${ }^{79}$ Id. at 138-39 (statement of Dr. Brayfield).

"The MMPI can by itself be a helpful source of hypotheses about and insights into the personality of an individual, but its most effective use is in combination with other information about that individual-if age, sex, education, occupation, and the like are known, and clinical observations available, as well as test results, any analysis and predictions will obviously be mucls more accurate than if one kind of information alone is relied on." Good \& Brantwer, The Physician's Guide to the MMPI 6 (1961). (Emphasis added.)

The question thus becomes whether the tests are utilized as part of a full-scale medical inquiry. In this connection, Dr. Zigmond Lebensohn of the American Psychiatric Association told the Subcommittee:

"The use of psychological tests in government agencies contrasts sharply with the use of tests in medical settings where ... test results are but one source of data which is combined with a great deal of other information from other experts to establish a medical diaguosis. The safeguards provided by the medical setting are often lacking in the personnel office of a government agency." Hearings Transcript 210. See VERNON, Personality Assessment: A Critical Survey 267 (1964).

${ }^{20}$ Hearings Transcript 139-40 (statement of Dr. Brayfield).
} 
scientifically reliable and valid. They say, for example, that answers to the MMPI have meaning because the developers of the test were "careful empiricists." That is to say, "the test is valid because experience validates it, though no answer is, itself, valid."81 No one answer is "correct" or "incorrect"; rather only a constellation of certain answers has meaning, for "experience ... shows that certain constellations of answers are given by people possessing certain characteristics."82 Proponents concede that people of similar characteristics may answer many questions quite differently, but this merely demonstrates that nothing is necessarily determined by isolated answers. The MMPI, the argument proceeds, is not a tool for selection of a person for his skill, education, or training. "It only seeks to measure emotional components to determine the probable state of emotional equilibrium." 83

Various witnesses claimed that with the help of personality inventories, personnel people have a better chance of selecting acceptable employees. Tests are said to be a valuable addition to the personal interview as a source of applicant evaluation. The chief psychologist at St. Elizabeth's Hospital told the Subcommittee:

[I]t has been quite well demonstrated that more people lose jobs because they cannot adjust to their fellows than because they cannot do the required tasks.

Intelligence, aptitude, and skill are not enough to insure success. ... .

Personality testing, interpreted by a competent professional psychologist, will in my opinion give a better evaluation of what the person is really like than other methods short of prolonged personality study ${ }^{84}$

She cautioned, however, that the "paper and pencil" tests are only screening devices, which may indicate those individuals who should be given a complete psychological examination and psychiatric interview. She further told the Subcommittee that no one should be disqualified on the basis of these tests alone. ${ }^{85}$

Numerous instances of research with groups are cited by

${ }^{81}$ Id. at 497 (statement of Dr. George K. Bennett, President, The Psychological Corporation).

${ }^{82}$ Ibid.

${ }^{83} I d$. at 498 (statement of Dr. Bennett).

${ }^{84}$ Id. at 184 (statement of Dr. Margaret Ives).

${ }^{85} I d$. at 185-86 (statement of Dr. Ives). 
psychologists to establish the validity of the tests. ${ }^{86}$ It is acknowledged by test advocates, however, that there is also research which casts doubt upon the effectiveness of the tests in at least some circumstances. ${ }^{87}$ Validity of the tests rests in the responsibility of the test administrator to know which tests are effective for what purposes and under what conditions. The importance of proper use of tests to insure the rights of the individual being evaluated cannot be overstated, for as the Subcommittee was informed by Professor Grant Dahlstrom of the University of North Carolina, an authority on the MMPI:

In the same way that is impossible to defend all uses to which the MMPI has been applied, it is not possible to defend all personality, aptitude, or ability tests that have been published and distributed. In spite of the best efforts of the American Psychological Association and responsible test publishing Houses, a great many psychological instruments are put on the market without proper refinement and development. Different instruments have various kinds of defects, but one limitation almost all tests have in common is a lack of national standardization. ${ }^{88}$

The National Bureau of Standards was suggested as the logical agency to supply the normative and standardizing studies in psychological measurement. Federal support of test standardization would "greatly strengthen psychological instruments and provide safeguards against unfounded claims, biased scales and norms, and other misrepresentations about the merits of particular tests." 89

\section{F. The Case Against the Tests}

Criticism of existing procedures involving psychological testing has come from many sources-from employees both in private industry and at all levels of government service, from students, from private citizens responding to the publicity given to the existing uses of tests, from lawyers who found the tests morally and legally improper, from a number of psychologists, from cyberneticists, and

${ }^{80}$ Id. at 135-38 (statement of Dr. Brayfield).

${ }^{87}$ Id. at 565 (statement of Dr. W. Grant Dahlstrom, Professor, University of North Carolina). See, e.g., Freeman, Theory and Practice of Psychological Testing 570-80 (3d ed. 1962); VerNoN, op. cit. supra note 79, at 201, 267; Ellis, The Validity of Personality Questionnaires, 43 Psycholocical Bulr. 385-440 (1946); Shlien, Mental Testing and Modern Society, in Readings in Psychological. Tests and Measurements 336-43 (Barnette ed. 1964).

${ }^{88}$ Hearings Transcript 569 .

so Id. at 570 (statement of Dr. Dahlstrom). 
from those in personnel management who advocate an intuitive approach to personnel selection based on traditional reference-oriented data.

Martin L. Gross, author of a popular study on psychological testing, ${ }^{00}$ told the Subcommittee that there has never been in the history of psychology a single validated psychological test nor a single successful experiment which indicated that a personality test predicted emotional behavior. ${ }^{91} \mathrm{He}$ summarized the controversy over testing which exists among psychologists and described the scientific gap which he found between psychological research with groups and the application of these findings to individuals. ${ }^{02}$

Some opponents of personality testing attack it because they believe that it is based upon invalid premises and research-in other words, that it does not do what it is supposed to do. ${ }^{93}$ Government

${ }^{\circ 0}$ Gross, The Brain Watchers (1962).

${ }^{21}$ Hearings Transcript 79 (statement of Mr. Gross).

${ }^{02} \mathrm{Id}$. at 78-92 (statement of Mr. Gross). A similar but somewhat less extreme finding is that of Ellis, supra note 87 , at 425 , who states after an extensive review of the literature in the field:

"We may conclnde . . that judging from the validity studies on group-ad. ministered personality questionnaires ... there is at best one chance in two that these tests will validly discriminate between groups of adjusted and maladjusted individuals, and there is very little indication that they can be safely used to diagnose individual cases or to give valid estimations of the personality traits of specific respondents. The older, more conventional, and more widely used forms of these tests seem to be, for practical diagnostic purposes, hardly worth the paper on which they are printed. Among the newer questionnaires, the Minnesota Multiphasic schedule appears to be the most promising one-perhaps because it gets away from group administration which has hitherto been almost synonymous witl personality test-giving. More research in this direction is well warranted at the present time." (Emphasis in original.)

${ }^{93}$ Consider, for example, the following remarks: "Ellis (1946), and Ellis and Conrad (1948) published valuable critical surveys of personality questionnaires, showing low frequently they fail to agree witlı external criteria of the traits they are supposed to measure. Some of the weaker instruments may have dropped out of use since then, and some better ones have been constructed. But the trend of innumerable subsequent investigations is that they cannot be trusted. The median validity coefficient-probably around $0.4-$ is by no means negligible, though hardly sufficient to jnstify using the tests for individual diagnosis. But the trouble is rather the variability-tests working fairly well in one investigation, not in another. . . . Considering all the effort and skill that has gone into producing better tests, from the late 1920's onwards, it is surprising low little progress has been made." VERNON, op. cit. supra note 79 , at 201 .

Another critic lias made the following charge: "[T] the tests . . . do not do what they are supposed to do. They do not do what they are supposed to do because, for one thing, they are not scientific. Neither in the questions nor in the evaluation are they neutral, they are, instead, loaded with debatable assumptions and questions of values. The result, deliberate or not, is a set of yardsticks that reward the conformist, the pedestrian, the unimaginative-at the expense of the exceptional individual whom managment most needs to attract." Whyte, The Fallacies of "Personality" Testing, in Readings in Psychological Tests and Measurenents 312 (Barnette ed. 1964). And see authorities cited note 79 supra. 
officials, it is argued, are wrong in assuming the professional adequacy of these devices. At one point Mr. Gross told the Subcommittee that "personality testing is closer to alchemy and to other nonsciences than it is to the truth. ... 'The inventories, the projective tests-all of them-are scarcely beyond the tea-leaf reading stage.' "94

The Subcommittee was told that group tests cannot be used for individual diagnoses because of their inability to distinguish accurately various personality traits in any given circumstance. ${ }^{95}$ Some experts believe the validity of the tests becomes less important when they are used-as by the armed forces-merely to place individuals in various general categories.96 It is little comfort, however, to the disappointed applicant for employment to conjecture that he is another statistic among those erroneously stigmatized by the tests.

Furthermore, the MMPI was criticized as based on a logical fallacy. That test was developed from responses to questions asked of 800 psychotic patients at the University of Minnesota Hospital and of 700 visitors to the hospital. The theory appears to be that, because the psychotics made high scores compared with the "normal" people, the test could be given to an individual to see if he is emotionally disturbed. It is charged, however, that this procedure "violates the basic rules of psychology." 97 r. Gross drew an analogy between this situation and group crime statistics:

It is very much like somebody saying that a certain minority group has a high crime rate as a group; and, therefore, if a man of that minority group is up for trial in court, then you say that statistically the chances are XYZ that he is going to be a criminal, because he belongs to the group.

What happens is that you may have more psychotic people getting high scores than normal people, but a large, large number of normal people get supposed psychotic scores on the multiphasic tests. ${ }^{98}$

Numerous examples were cited of futile attempts by the Government, the armed services, private industry, and even the United $\mathrm{Na}$ tions to validate the tests during screening programs. ${ }^{99}$

${ }^{\circ}$ Hearings Transcript 77-78 (statement of Mr. Gross, quoting Dr. Henry S. Dyer, Vice President, Educational Testing Service).

${ }^{05} \mathrm{Id}$. at 79 (statement of Mr. Gross). See note 92 supra.

'See Ellis \& Conrad, The Validity of Personality Inventories in Military Practice, 45 Psychological Bull. 385 (1948).

${ }^{97}$ Hearings Transcript 84 (statement of Mr. Gross).

98 Ibid.

${ }^{\circ 0} \mathrm{Id}$. at 80-83 (statement of Mr. Gross). 
Other factors have a strong bearing on the scientific worth of personality testing. For example, the circumstances surrounding the administration of the test may affect the subject and cause him to display certain characteristic forms of behavior. If there is an interaction between the tester, the subject, and their environment, this situation would not correspond to the basic premises of the original research and would thus seriously impair the usefulness of the testing to the government agencies. Psychology Professor Karl $U$. Smith of the University of Wisconsin reported the results of studies made in prisons, industries, and educational institutions which demonstrated the feedback effects of environment, personality of the tester, and other influences upon the test responses. Applying the principles of cybernetics or systems analysis to testing, he concluded that:

(a) psychological testing has no critical relations with experimental psychology or any other branch of experimental science and reflects none of the recent advances in scientific understanding of the mechanisms of behavior;

(b) testing is based purely on estimating deviations from social norms and has no significant means within itself of dealing with the individual;

(c) there are no objective scientific principles to guide test construction;

(d) the criterion groups or population samples against which tests are originally validated by no means represent the population as a whole; that is to say, representative samples have never been used in this field;

(e) test research in schools and industry is rarely objective and unbiased, and test validation programs have rarely been free of the influence of on-going personnel and administrative operations. ${ }^{100}$

Opponents of all testing charge that it provides a type of "group statistical guilt." 101 Some members of Congress deplored the loophole left by the Civil Service Commission directive which allows testing in "medical situations." According to Mr. Gross this is "really pseudo scientific testing [which] is an extra-legal situation." 102 The Subcommittee was told that the employee is confounded because he cannot go to his doctor, lawyer, or anyone else for help. ${ }^{103}$ There is a grave

${ }^{100} \mathrm{Id}$. at 262 (statement of Mr. Smith).

${ }^{101}$ E.g., id. at 90 (statement of Mr. Gross).

102 Ibid.

108 Ibid. 
danger that a person could be falsely labeled neurotic, schizophrenic, or emotionally disturbed. By falsely labeling individuals -a phenomenon called "false positives"-we are in essence penalizing citizens on the basis of an extra-legal concept of punishment. They have committed no antisocial behavior; their test scores merely vary from a group norm. As Mr. Gross was moved to charge: "In this tyranny of group statistical guilt, there are no safeguards, no psychological habeas corpus, no impartial judge or jury to review or rebuke or to even find that the tests are in scientific contempt."104

That there are very real problems in the non-therapeutic use of psychological tests by government is admitted even by psychiatrists who advocate their use. The problems which they envision are limited, however, to confidentiality of test information and qualification of persons administering the tests. ${ }^{105}$ Dr. Zigmond Lebensohn told the Subcommittee that the system under which the tests are given should contain safeguards that are similar in their effectiveness to those which prevail in medical settings. Safeguards must be developed which will protect applicants for employment and promotion "from inappropriate use of the tests and unjust verdicts based on isolated test results." 106

Although the doctor-patient relationship is privileged by the laws of two-thirds of American jurisdictions, ${ }^{107}$ this protection is not afforded in government settings where test results become a matter of record. ${ }^{108}$ Given the procedural gaps which exist and the broad area for discretion, there is always a possibility that test results may be used by nonprofessional persons for purposes for which they were never intended. The Peace Corps, which has been widely criticized in this respect, has now changed its policy and destroys the test results. ${ }^{109}$ However, other agençies have not done so; and

\footnotetext{
${ }^{104} \mathrm{Id}$. at 91 (statement of Mr. Gross).

${ }^{105}$ As Dr. Zigmond M. Lebensohn of the American Psychiatric Association noted:

"The trouble is, of course, that in our present stage of development, the tests can be, and no doubt are, frequently given by persons who are inadequately trained to administer and interpret them. Some tests are more reliable than others. The wrong tests can be given to the wrong person. The results can be misinterpreted. Excessive reliance can be placed on a single test result. Thus an injustice could be done." Id. at 209.

${ }^{100} \mathrm{Id}$. at 214 (statement of Dr. Lebensohn).

${ }^{107}$ See MCCORMrICK, EvidENCE 211 (1954). The various statutes on the doctor-patient privilege are quoted in 8 WIGMORE, EvideNCE $\S 2380 \mathrm{n} .5$ (MCNaughton rev. 1961), and on the psychologist-patient privilege in id. $\S 2286 \mathrm{n} .23$.

${ }^{108}$ See Hearings Transcript 34 (testimony of Dr. Woodward).

${ }^{100} \mathrm{Id}$. at 310 (statement of Dr. Carp).
} 
there is no guarantee that even the Peace Corps' policy will not be changed administratively in the future. Severe restrictions upon availability and circulation of medical records would be one control which Congress might establish.

\section{III}

\section{The Constitutional Case Against Testing}

As we have pointed out, there exists no body of case law concerning psychological testing as a condition or incident of government employment. ${ }^{110}$ Therefore, any guidelines which the courts may in the future lay down in this area must evolve from one or more present trends of constitutional development. The first of these is the law regulating the employment relationship where the Government is the employer. The inquiry here relates to the Government's power to impose conditions upon that relationship and the extent to which this power is circumscribed by the due process clause of the fifth amendment. ${ }^{111}$ The second trend concerns recent developments which define, however vaguely, a constitutional right of privacy.112

A view widely held among psychologists, administrators and even members of Congress is that federal employment is not a "right" but a "privilege." This leads to the immediate and facile conclusion that personality testing-or any other requirement, for that matter -may be made a condition of public employment regardless of any adverse consequences to the individual. This right-privilege dichotomy receives inspiration from Mr. Justice Holmes' famous epigram in McAuliffe $v$. Mayor \& $B d .^{113}$ to the effect that an individual "may have a constitutional right to talk politics, but he has no constitutional right to be a policeman."114 This approach finds certain support in those decisions which have held that the fifth amendment does not apply to dismissals from the federal civil

\footnotetext{
110 See note 2 supra and accompanying text.

111 "No person shall ... be deprived of life, liberty, or property without due process of law ...."

Some of the most significant cases in this area, such as Slochower $v$. Board of Higher Educ., 350 U.S. 551 (1956) and Wieman v. Updegraff, 344 U.S. 183 (1952) involved employees of state, not federal, governments, as employer and thus were decided on the basis of the fourteenth amendment's due process clause. Nevertheless, the constitutional concepts underlying inquiry under either amendment are probably identical.

112 See note 2 supra and accompanying text.

113155 Mass. 216, 29 N.E. 517 (1892).

114 Id. at 220, 29 N.E, at 517.
} 
service on the theory that a position with the Government constitutes neither "life," "liberty," nor "property."115 Furthermore, the Supreme Court held in United Public Workers of America $v$. Mitchell ${ }^{116}$ that the restrictions imposed by the Hatch Act ${ }^{117}$ upon participation by public employees in political activities are not prohibited by the first, fifth, ninth, or tenth amendments.

However, this right-privilege approach requires closer scrutiny. In the first place, a number of the cases have explicitly imposed a reasonableness criterion upon a government's actions with respect to its employees. In the $M c$ Auliffe case, for example, $\mathrm{Mr}$. Justice Holmes stated that "the city may impose any reasonable condition upon holding offices within its control."118 The Supreme Court in Mitchell found that the restriction upon political activity was necessary to prevent that which could be "reasonably deemed by Congress to interfere with the efficiency of the public service."119 The Court also insisted that employees may not be arbitrarily disqualified from government service. ${ }^{120}$

The establishment following World War II of extensive loyaltysecurity programs throughout the federal and state governments and in private industry presented threats to liberties so basic as to require redefinition of employees' constitutional rights. ${ }^{121}$ The "facile generalization"122 of a right-privilege dichotomy was rejected, and the due process test of "the protection of the individual

${ }^{215}$ Taylor v. Beckham (No. 1), 178 U.S. 548 (1900); Angilly v. United States, 199 F.2d 642 (2d Cir. 1952); Bailey v. Richardson, 182 F.2d 46 (D.C. Gir. 1950), aff'd per curiam by equally divided court, 341 U.S. 918 (1951).

Public employment is a "privilege revocable by the sovereignty at will." Crenshaw v. United States, 134 U.S. 99, 108 (1890) (naval officer). This is in sharp contrast to the view of the Court that the right to hold specific private employment is within the "liberty" and "property" concepts of the fifth and fourteenth amendments' due process clause. See Willner v. Committee on Character \& Fitness, 373 U.S. 96, 102 (1963); Greene v. McElroy, 360 U.S. 474, 492 (1959); Schware v. Board of Bar Examiners, 353 U.S. 232, 238-39 (1957); Peters v. Hobby, 349 U.S. 331, 352 (1955) (concurring opinion).

${ }_{110} 330$ U.S. 75 (1947).

${ }_{117}$ Section 9 (a), 53 Stat. 1148 (1939), as amended, 5 U.S.C. § $118 \mathrm{i}$ (a) (1964).

118155 Mass. at 220, 29 N.E. at 518. (Emphasis added.)

110330 U.S. at 101. (Emphasis added.)

120 "Congress may not "enact a regulation providing that no Republican, Jew or Negro shall be appointed to federal office ....'" Id. at 100 (dictum). See Garner v. Board of Pub. Works, 341 U.S. 716, 725 (1951) (Frankfurter, J., concurring).

${ }^{121}$ See generally Association of tHE BAR of THE CITY OF NEW YORK, REPORT OF the Special Committee on the federal Loyalty-Security Program (1956); Barth, The Loyalty of Free Men (1951); Bontecou, The Federal Loyalty-Segurtty Program (1953).

${ }^{122}$ Wieman v. Updegraff, 344 U.S. 183, 191 (1952). 
against arbitrary action"123 began to make its way into the opinions. Thus in Wieman v. Updegraf,, ${ }^{124}$ in which an Oklahoma statute requiring loyalty oaths for state employees was voided, the Court stated: "We need not pause to consider whether an abstract right to public employment exists. It is sufficient to say that constitutional protection does extend to the public servant whose exclusion pursuant to a statute is patently arbitrary or discriminatory." 125 Four years later, the Court in Slochower v. Board of Higher Educ. ${ }^{\mathbf{1 2 0}}$ invalidated action under a state law requiring the automatic dismissal of employees who pleaded the fifth amendment with the following observation: "To state that a person does not have a constitutional right to government employment is only to say that he must comply with reasonable, lawful, and nondiscriminatory terms laid down by the proper authorities." 127 Thus it appears that the Slochower-Wieman approach places "constitutional restraints upon state and federal governments in dealing with their employees ...."128 Whether or not an abstract "right" to public employment exists is irrelevant. ${ }^{129}$ The Government is restrained in regulating its relationship to its employees by the due process notion of reasonable action-action which is neither arbitrary nor discriminatory. ${ }^{139}$

\footnotetext{
${ }^{123}$ This phrase originally appeared in Ohio Bell Tel. Co. v. Public Util. Comm'n, 301 U.S. 292, 302 (1937).

124344 U.S. 183 (1952) (fourteenth amendment).

125344 U.S. at 192.

120350 U.S. 551 (1956) (fourteenth amendment).

127350 U.S. at 555.

Professor Davis suggests that "The Court could have expressed the essence of its thought more simply: to state that a person does not have a constitutional right is only to say that he does have a constitutional right. . . . The Court has amply demonstrated a capacity to manipulate the doctrine [of privilege] out of existence, or to disable it temporarily or partially, as the occasion may require." Davis, The Requirement of a Trial-Type Hearing, 70 HARv. L. REv. 193, 230, 232 (1956).

The comments in Slochower should be compared to those in Adler v. Board of Educ., 342 U.S. 485, 492 (1952):

"It is ... clear that they [public school teachers] have no right to work for the State in the school system on their own terms. United Public Workers v. Mitchell, 330 U.S. 75. They may work for the school system upon the reasonable terms laid down by the proper authorities of New York." (Emphasis added.)

${ }^{128}$ Cafeteria Workers Union v. McElroy, 367 U.S. 886, 898 (1961) (dictum) (employee of private restaurateur located on military base denied security clearance).

${ }^{129}$ Sec Cramp v. Board of Pub. Instruction, 368 U.S. 278, 288 (1961). “"One may not have a constitutional right to go to Baghdad, but the Government may not prohibit one from going there unless by means consonant with due process of law.'" Cafeteria Workers Union v. McElroy, 367 U.S. 886, 894 (1961) (dictum).

${ }^{130}$ See Cafeteria Workers Union v. McElroy, 367 U.S. 886, 897-98 (1961); Davis, supra note 127, at 239 \& n.170; Krasnowiecki, Confrontation by Witnesses in Govern.
} 
We may now proceed to apply this "reasonableness" test under certain more specific headings to the Government's use of psychological tests. This will be done by a consideration of the following questions: (A) Is psychological testing reasonably related to the ends sought to be achieved by its use? (B) Must an employee who undergoes such testing be allowed to present psychological evidence in rebuttal? (C) Is psychological testing analogous in the employeremployee situation to involuntary confessions and self-incrimination? (D) Does the employee have a "right of privacy" which is invaded by testing under some or all circumstances?

\section{A. Reasonably Related to the Desired Goal}

In the first instance, it must be pointed out that the "reasonableness" test has most frequently been applied to legislative action. ${ }^{131}$ However, where departments and agencies rely upon general statutes for rule-making powers over their employees, it would be logically inconsistent to suggest that the legislature is constrained by notions of due process but that the various departments have a completely free hand to act. ${ }^{132}$ If in accordance with traditional due process concepts the agencies may only act in a manner reasonably calculated to achieve their legitimate ends, ${ }^{133}$ it could be argued that

ment Employee Security Proceedings, 33 Notre Dame Law. 180, 191 (1958); Nutting, The Fifth Amendment and Privacy, 18 U. PitT. L. Rev. 533, 540 (1957); Richardson, Problems in the Removal of Federal Civil Servants, 54 Mich. L. Rev. 219, 235-45 (1955); The Supreme Court, 1950 Term, 65 HARv, L. Rev. 107, 158 (1951); 46 CaLIF. L. REv. 828, 829 (1958); 2 Hous. L. REv. 120, 124-25 (1964).

${ }^{232}$ E.g., Wieman v. Updegraff, 344 U.S. 183 (1952); Slochower v. Board of Higher Educ., 350 U.S. 551 (1956).

${ }^{132}$ See United States v. Rasmussen, 222 F. Supp. 430 (D. Mont. 1963); 2 Hous. L. REv. 120, 124 (1964). "An administrative agency-the creature of Congress-certainly cannot exercise powers that Congress itself is barred from asserting. See the opinion of MR. JUSTICE BLACK in Anti-Fascist Committee v. McGrath, 341 U.S. 123, 144-46." Peters v. Hobby, 349 U.S. 331, 352 (1955) (Douglas, J., concurring). (Footnote omitted.)

${ }^{133}$ The interest of the Government in the area of personnel selection, of course, is the advancement of the government civil service. By statute the President is required to promulgate such rules regarding admission to the federal service "as may best promote the efficiency thereof.” REv. STAT. $\$ 1753$ (1875), 5 U.S.C. $§ 631$ (1964).

With this in mind, consider the following remarks interpreting the due process clause of the fourteenth amendment: "[T] guaranty of due process . . . demands only that the law shall not be unreasonable, arbitrary, or capricious, and that the means selected shall have a real and substantial relation to the object sought to be attained." Nebbia v. New York, 291 U.S. 502, 525 (1934); see Williamson v. Lee Optical, Inc., 348 U.S. 483, 489 (1955).

More importantly, "where there is a significant encroachment upon personal liberty, the State may prevail only upon showing a subordinating interest which is compelling." Bates v. Little Rock, 361 U.S. 516, 524 (1960); see McLaughlin v. Florida, 379 U.S. 184, 196 (1964). 
psychological testing is purely arbitrary and therefore does not meet this criterion. Even if some nexus can be shown between promoting the efficiency of the federal service and the use of psychological tests, the serious infringement on personal liberty which results from such tests would compel that the nexus be clearly indicated. To the extent that congressional hearings and numerous other studies indicate that psychological tests lack reliability and validity in employment situations and result in arbitrary personnel decisions, a prohibition of such techniques should result. ${ }^{134}$

\section{B. Right to Rebut Test Evidence}

If it be argued that psychological testing may have some usefulness as a screening device but that it is by no means an accurate indicator in every instance, the question arises as to whether the employee should be able to present his own rebutting psychological data-to "cross-examine" the tests. ${ }^{135}$ The Supreme Court has given rather little guidance to indicate which procedures are necessary to insure that the requirements of due process are met. Traditionally the courts have treated admission, promotion, and dismissal from the civil service as matters to be dealt with by the executive branch. ${ }^{136}$ Therefore, rather than set down standards of its own, the Supreme Court in recent years has contented itself with scrutinizing the details of particular cases to make certain that the various departments have rigidly adhered to whatever procedural rules they may have enacted. ${ }^{137}$ Thus the constitutional issue has been avoided.

\footnotetext{
134 See part II F of this article; note 133 supra.

${ }^{135}$ As Senator Sam J. Ervin, Jr., pointed out: "[T]he analogy can be drawn perhaps that if the employee has a right to confront his accusers in some proceedings, then perhaps he should confront the psychological tests and the psychiatric reports which may cast a cloud over his emotional stability and his mental competency. In a sense, they are the accusers. Certainly, the procedural rights in this area should be carefully spelled out." Hearings Transcript 6.

${ }^{136}$ See Richardson, supra note 130, at 239. Thus it was said in 1947 that "because of the courts' reluctance to interfere with government action taken against its $\mathrm{cm}$. ployees, their protection lies largely with the president, and, to some extent, with Congress." Note, Restrictions on the Civil Rights of Federal Employees, 47 Colum. L. REv. 1161, 1188 (1947).

${ }^{132}$ E.g., Williams v. Zuckert, 371 U.S. 531 (1963); Greene v. McElroy, 360 U.S. 474 (1959); Vitarelli v. Seaton, 359 U.S. 535 (1959); Cole v. Young, 351 U.S. 536 (1956); Peters v. Hobby, 349 U.S. 331 (1955).
} 
Most of these cases relating to employees' rights have involved aspects of the Government's loyalty-security program. The possible connections between this program and psychological testing have already been noted. ${ }^{138}$ The Court has been particularly concerned that aspersions cast upon one's loyalty may constitute a bar to future employment. ${ }^{139}$ Insofar as findings based upon psychiatric techniques and psychological testing may also result in such a bar, the Court could very well turn to the dicta in the security decisions. For example, in Greene v. McElroy, ${ }^{140}$ which was not decided on constitutional grounds, the Court commented:

Certain principles have remained relatively immutable in our jurisprudence. One of these is that where governmental action seriously injures an individual, and the reasonableness of the action depends on fact findings, the evidence used to prove the Government's case must be disclosed to the individual so that he has an opportunity to show that it is untrue. While this is true in the case of documentary evidence, it is even more important where the evidence consists of the testimony of individuals whose memory might be faulty .... We have formalized these protections in the requirements of confrontation and cross-examination. ${ }^{141}$

Justices Black and Douglas have been the most consistent supporters of full procedural safeguards "whether the life of a man is at stake, or his reputation, or any matter touching upon his status or his rights." 142 They analogize administrative proceedings which adversely affect an individual's employment opportunities to those that "involve the imposition of criminal sanctions." 143 Confrontation and cross-examination are indispensable, for it is not only the opportunity to work in one specific government office which is at stake;

${ }^{138}$ See note 12 supra and accompanying text.

${ }^{130}$ See, e.g., Greene v. McElroy, 360 U.S. 474, 506-08 (1959).

"[The practice of using 'faceless informers'] . . deprives men of 'liberty' within the meaning of the Fifth Amendment, for one of man's most precious liberties is lis right to work. When a man is deprived of that 'liberty' without a fair trial, he is denied due process." Peters v. Hobby, 349 U.S. 331, 352 (1955) (Douglas, J., concurring).

160360 U.S. 474 (1959).

141360 U.S. at 496 .

142 United States v. Nugent, 346 U.S. 1, $13-14$ (1953) (Douglas and Black, JJ., dissenting). See Cafeteria Workers Union v. McElroy, 367 U.S. 886, 900-01 (Brennan, J., dissenting).

${ }^{263}$ Williams v. Zuckert, 371 U.S. 531, 533 (1963) (Douglas and Black, JJ., dissenting). 
rather, "the stigma now attached to ... [the employee] will follow him, whatever employment he seeks." 144

Furthermore, the Court in Greene suggested that where an individual's professional opportunities are restricted without full procedural safeguards, it must be clear that "the President or Congress, within their respective constitutional powers, specifically has decided that the imposed procedures are necessary and warranted and has authorized their use."145 If the Court were presented with evidence that employment opportunities had been limited for persons whose emotional stability is questioned on the basis of psychiatric interviews and psychological testing by government, and who might also ipso facto become "security risks," the Court could rule on the basis of past dicta and dissents that a hearing, confrontation of witnesses, and cross-examination are constitutionally required..$^{146}$ Alternatively, and more consistently with past decisions, the Court could require that psychological testing be explicitly authorized by either Congress or the President.

Finally, in this connection, it has been frequently noted that due process is not a "stagnant formulation" 147 but an evolutionary standard which requires a balancing of private and governmental interests. ${ }^{148}$ Given the possibility of grave harm to the individual caused by an adverse psychiatric diagnosis, it is unclear whether the Government has any interest in the summary use of such devices without allowing the employee a chance to rebut their analysis. A Court of Appeals has made the following observations:

$[W]$ e must weigh against the rights of the individual to the traditional opportunity for notice and hearing, the public need for a screening system which denies such right to notice and hearing. Granted that the Government may adopt appropriate means for excluding security risks from employment ...., what is the factor of public interest and necessity which requires that it be done in the manner here adopted? ${ }^{149}$

\footnotetext{
${ }^{144}$ Id. at 534 .

145360 U.S. at 507.

${ }^{246}$ See note 26 supra.

${ }^{147}$ Malinski v. New York, 324 U.S. 401, 414 (1945) (Frankfurter, J., concurring).

${ }^{148}$ See Cafeteria Workers Union v. McElroy, 367 U.S. 886, 894-95 (1961).

${ }^{149}$ Parker v. Lester, 227 F.2d 708, 718 (9th Cir. 1955). (Emphasis in original.) Davis suggests that the Parker approach be extended to all federal employees. Davis, supra note 127 , at 239.
} 
C. The Analogy to Involuntary Confessions and Self-Incrimination

There are those who take an even dimmer view of psychological testing and would ban it completely as a government personnel screening device. The argument may be expressed in the following terms: Because of the social stigma attached to adverse test results, the employee should be given "the same right $[\mathrm{s}]$... as he would have in a criminal trial."150 The search and seizure of the contents of men's minds by a forced submission to psychological testing should be denounced as offensive to "those canons of decency and fairness which express the notions of justice of English-speaking peoples."151 A comparison can be made to the pumping of a man's stomach in order to obtain evidence of illegal narcotics possession, a practice which was condemned by the Court in Rochin v. California. ${ }^{152}$ To the extent that the analogy to criminal proceedings can be maintained, it is obvious that there are also self-incrimination objections to the utilization of test scores involuntarily received as a basis for adverse action against the employee.

Confronted with this line of reasoning in the hearings, legal counsel for the executive branch answered that such decisions as Rochin involved forced searches and involuntary confessions. In contrast, it was stated, testing under government auspices is voluntary. The applicant or employee consents to it. ${ }^{153}$ Unfortunately, this conclusion is not borne out by the hearings and individual cases studied by the Subcommittee on Constitutional Rights. A man can hardly be said to consent voluntarily when he knows that he will probably not be hired if he does not submit to testing, that he may be dismissed from his job, or that he will be reprimanded for insubordination if he fails to submit to a psychiatric examination which may involve testing. On the contrary, as Senator Ervin pointed out,

\footnotetext{
${ }^{150}$ Williams v. Zuckert, 371 U.S. 531, 534 (1963) (Douglas, J., dissenting) (right of confrontation).

${ }^{151}$ Rochin v. California, 342 U.S. 165, 169 (1952) (involuntary incrimination). This, of course, is a formulation of the "natural law" concept of due process, which refers to "those personal immunities which .... are 'so rooted in the traditions and conscience of our people as to be ranked as fundamental,' Snyder v. Massachusetts, 291 U.S. 97, 105, or are 'implicit in the concept of ordered liberty.' Palko v. Connecticut, 302 U.S. 319, 325." Ibid. This approach allows the Justices a certain discretion to balance the various interests involved before finding a violation of due process. See Cafeteria Workers Union v. McElroy, 367 U.S. 886, 894-95 (1961).

15: 342 U.S. 165 (1952).

${ }^{153}$ See, e.g., Hearings Transcript 15 (testimony of William J. Crockett, Under Secretary of State for Administration).
} 
" $\mathrm{a}$ fair, plausible case [can] be made out for the proposition that a job applicant is ordinarily [under] a form of economic coercion." ${ }^{15 a}$ Furthermore, consent is meaningless unless the examinee knows to what he is consenting. ${ }^{155} \mathrm{He}$ may know the questions, but he does not know the answers, the purposes for asking the questions, or the inferences which may be drawn as to his personality categorization. Most of the tests depend in substantial part for their success upon the ignorance of the examinee as to precisely what he is being tested about. ${ }^{156}$ In any event, should psychological testing be found to be constitutionally suspect, the issue of "voluntariness" would probably disappear, since the Government presumably could not maintain an unconstitutional condition as a prerequisite to employment. .157 $^{15}$

\section{The "Right of Privacy"}

The final constitutional blow to be struck against psychological testing derives from the evolving notion of a "right of privacy." 158 This newest of constitutional rights was initially an aspect of the fourth amendment's search and seizure clause and the self-incrimination provision of the fifth amendment. ${ }^{159}$ However, it received an independent status in Griswold $v$. Connecticut, ${ }^{160}$ grounded on the penumbras of the specific guarantees of the Bill of Rights, ${ }^{101}$ the concept of "liberty" contained within the due process clause of the fourteenth amendment, ${ }^{102}$ and the ninth amendment. ${ }^{103}$

The Griswold case, of course, concerned Connecticut's ill-fated

\footnotetext{
104 Id. at 371 .

205 See note 4 supra.

${ }^{250}$ See, e.g., Hearings Transcript 368-69 (statement of Monroe H. Freedman, Associate Professor of Law, George Washington University).

${ }^{167}$ See Richardson, supra note 130, at 243-44.

158 See note 2 supra and accompanying text.

${ }^{150}$ See, e.g., Mapp v. Ohio, 367 U.S. 643, 656.57 (1961) (dictum); Boyd v. United States, 116 U.S. 616, 630 (1886). See generally Beaney, The Constitutional Right to Privacy in the Supreme Court, 1962 SuP. Cr. REv. 212; Nutting, supra note 130. It has also been said that "the right to privacy implicit in the First Amendment creates an area into which the Government may not enter." Gibson v. Florida Legislative Investigation Comm., 372 U.S. 539, 570 (1963) (Douglas, J., concurring).

100381 U.S. 479 (1965).

101 Id. at 484 (opinion of the Court by Douglas, J.).

${ }^{102}$ Id. at 500 (Harlan, J., concurring); id. at 486 (Goldberg, J., concurring). Sec Poe v. Ullman, 367 U.S. 497,539 (1961) (Harlan, J., dissenting) (fifth and fourteenth amendments); Silverman v. United States, 275 F.2d 173, 179 (D.C. Cir. 1960) (Washington, J., dissenting), reversed, 365 U.S. 505 (1961) (fifth amendment); Nutting, supra note 130 , at 544 .

${ }^{183} 381$ U.S. at $491-92$ (Goldberg, J., concurring).
} 
attempt to prevent by statute anyone, including married couples, from using contraceptive devices. Nevertheless, if the Supreme Court's recent excursions into other areas is any indication, we may confidently expect the right of privacy to be given an ever-widening scope. $^{164}$ Some commentators have suggested the extension of Griswold to sexual conduct outside the marital relationship, to wiretapping and eavesdropping, to official inquiries into the private lives of welfare recipients, ${ }^{105}$ and to governmental efforts to compel individuals to disclose information through such means as legislative committees and the lie-detector. ${ }^{106}$ Psychological testing is hardly removed in kind from these Jatter categories. ${ }^{167}$

Of course, this constitutional right of privacy is not well defined. ${ }^{168}$ Nevertheless, its underlying philosophy was concisely stated many years ago in the following passage written by Mr. Justice Brandeis:

The makers of our Constitution undertook to secure conditions favorable to the pursuit of happiness. They recognized the sig-

\footnotetext{
${ }^{10 *}$ Consider, e.g., the reapportionment cases, especially Reynolds v. Sims, 377 U.S. 533 (1964), and Lucas v. Forty-Ninth General Assembly, 377 U.S. 713 (1964), and the school prayer case, Engel v. Vitale, 370 U.S. 421, 437 (1962) (Douglas, J., concurring).

${ }_{105} \mathrm{Cf}$. Reich, Individual Rights and Social Welfare: The Emerging Legal Issues, 74 YALE L.J. 1245, 1247-48, 1254 (1965).

${ }^{100}$ See Emerson, Nine Justices in Search of a Doctrine, 64 Mich L. REv. 219, 231-34 (1965); McKay, The Right of Privacy: Emanations and Intimations, 64 MicH. L. REv. 259, 272-82, (1965).

${ }_{107}$ On the general issue of whether psychological testing constitutes an invasion of privacy, see Cronbach, Essentials of Psychological Testing 459-60 (2d ed. 1960): "Any test is an invasion of privacy for the subject who does not wish to reveal himself to the psychologist. While this problem may be encountered in testing knowledge and intelligence of persons who have left school, the personality test is much more often regarded as a violation of the subject's rights. Every man has two personalities: the role he plays in his social interactions and his 'true self.' In a culture where open expression of emotion is discouraged and a taboo is placed on aggressive feelings, for example, there is certain to be some discrepancy between these two personalities. The personality test obtains its most significant information by probing deeply into feelings and attitudes which the individual normally conceals. One test purports to assess whether an adolescent boy resents authority. Another tries to determine whether a mother really loves her child. A third has a score indicating the strength of sexual needs. These, and virtually all measures of personality, seek information on areas which the subject has every reason to regard as private, in normal social intercourse. He is willing to admit the psychologist into these private areas only if he sees the relevance of the questions to the attainment of his goals in working with the psychologist. The psychologist is not 'invading privacy' where he is freely admitted and where he lias a genuine need for the information obtained."

${ }^{108}$ See generally Symposium on the Griswold Case and the Right of Privacy, 64 MICH. L. REv. 197 (1965).
} 
nificance of man's spiritual nature, of his feelings and of his intellect. They knew that only a part of the pain, pleasure and satisfactions of life are to be found in material things. They sought to protect Americans in their beliefs, their thoughts, their emotions, and their sensations. They conferred, as against the Government, the right to be let alone-the most comprehensive of rights and the right most valued by civilized men. To protect that right, every unjustifiable intrusion by the Government upon the privacy of the individual, whatever the means employed, must be deemed a violation of the Fourth Amendment. ${ }^{100}$

This approach suggests that the freedom from intrusion by the Government upon both the citizen's physical and spiritual being is a value which lies at the very core of our traditions. Furthermore, Mr. Justice Brandeis counseled vigilance against the "subtler and more far-reaching means of invading privacy [which] . . . become available to the Government."'170 Certainly the psychological test is a device which falls into this category.

It has been said, however, that "the right of privacy . . . is not an absolute,"171 which suggests that a balancing approach would be followed. Given the interest of the individual employee in personal privacy, the Government would be required to demonstrate an overriding interest in the use of psychological tests. ${ }^{172}$ At a minimum this burden would probably necessitate a showing that the tests utilized are accurate, that testing is a reasonable means to ferret out the emotionally unstable who in turn constitute a significant threat to the efficiency of the federal service, and that alternative methods to testing are not available. Even where a superior public interest may warrant an invasion of personal privacy, the intrusion should be accompanied with complete procedural safegnards for the individuals affected. ${ }^{\mathbf{1 7 3}}$

\footnotetext{
${ }^{160}$ Olmstead v. United States, 277 U.S. 438, 478 (1928) (Brandeis, J., dissenting). $170 \mathrm{Id}$. at 473 .

171 Poe v. Ullman, 367 U.S. 497, 552 (1961) (Harlan, J., dissenting).

172 See note 133 supra and accompanying text. Cf. Griswold v. Connecticut, 381 U.S. 479, 495-96 (1965) (Goldberg, J., concurring); id. at 503.04 (White, J., concurring).

173 "Even where the public interest may warrant the taking of private property or of private personality, no absolute license is justified. The taking should be reasonable, it should be conducted with due process, and it should be limited to no more than what is necessary for the fulfillment of the public purpose which, in fact, warranted the invasion." Ruebhausen \& Brim, Privacy and Behavioral Research, 65 Colum. L. REv. 1184, 1202 (1965).
} 


\section{IV}

\section{Proposed Solutions to the Question of Testing}

The possibility of a successful constitutional attack on psychological testing in a court action appears to be a real possibility in the near future. The testimony received by the Constitutional Rights Subcommittee shows that existing procedures for psychiatric evaluations and psychological testing are deficient in terms of protection of employee rights.

The necessity for a court test, however, could be eliminated by changes in the current testing practices and procedures used by the Government. Various alterations in the present situation were suggested to the Subcommittee. One solution to at least part of the problem is to afford the employee, and perhaps the applicant, an effective means of challenging the psychological reports and the expertise of the psychologist. At the present time no such procedures are available. For example, the Committee on Standards for Government Employment of the District of Columbia Bar Association, reporting on a study of disability separation procedures, found that an employee has no effective legal recourse to an involuntary disability retirement which he feels is unwarranted. ${ }^{174}$ This is in sharp contrast to the means provided by Congress for armed forces personnel to challenge adverse retirement actions-which means include a full hearing and the right to counsel. ${ }^{175}$ It was recommended that such a system of hearing procedures be established for federal employees. Until such legislation becomes a reality, the Subcommittee was told, "a serious void, with irreparable ad-

176 "Among other things, the employee is exposed to the threat of disciplinary action if he does not comply with an order issued to report for a medical examination to determine his fitness or alleged unfitness for duty-an action which can be initiated by a layman. The employee has no means of effectively inquiring into the basis for the initial determination that he is unfit. The employee has no right to inquire into the medical qualifications of the medical examiner. He has no right to ascertain the adequacy of the evidence utilized in effecting his separation for disability. The employee has no forum to present medical evidence in his own behalf." Hearings Transcript 544 (statement of Byron N. Scott, Chairman, Comm. on Standards for Gov't Employment, D.C. Bar Ass'n).

${ }^{175}$ Congress has specifically provided that "no member of the armed forces may be retired or separated for physical disability without a full and fair hearing if he demands it." 10 U.S.C. § 1214 (1964).

For an analysis of the safeguards afforded the individual in administrative discharge action by the military, see Everett, Military Administrative Discharges-The Pendulum Swings, 1966 DukE L.J. 41. 
verse consequences to the individual, will continue to exist with regard to the Constitutional rights of the federal employee . . . ."170

The American Psychological Association holds the view that Congress may prescribe the roles and functions of psychologists in the federal government, but that it should not dictate the methods and procedures for carrying out these functions. Therefore, the Association proposes a type of professional autonomy for this group of specialists within the bureaucracy. However, the Association did offer several suggestions for safeguarding the rights of individuals subject to psychological assessment procedures. ${ }^{177}$

Another possibility is a severe limitation upon the circumstances in which testing might be used. ${ }^{178} \mathrm{~A}$ parallel could be drawn to Cole v. Young ${ }^{179}$ in which the Supreme Court limited the application of certain summary dismissal procedures to personnel intimately connected with the "national security."180 Because of the individual interest in privacy, psychological testing might be held-by legislation or judicial decision-to be justified only when this interest is outweighed by the actual presence of a genuine "national security" issue.

In the final analysis, a thorough-going reform of existing procedures relating to psychological testing is a matter which must be confronted by Congress. Congress must decide whether, in light of the evolving law surrounding the right of privacy and the employment

${ }^{170}$ Hearings Transcript 545 (statement of Mr. Scott).

${ }^{172}$ Hearings Transcript 147-49 (statement of Dr. Arthur H. Brayfield, Executive Director, American Psychological Ass'n). The Association proposed the following: Government should " 1 . Insure that all non-research test use and psychological assessment such as is not under the direct cognizance, or administration, of the Civil Service Commission [such as in the Peace Corps] should be under the direction of highly qualified staff psychologists directly responsible to operating or line administrators. 2. Maintain a review or appeal procedure for personnel decisions in which psychological test data and psychological assessment have had an important part, perhaps with the possible use of an outside panel composed in part of psychologists. 3. Establish an Interagency Committee on Assessment composed of representative agency psychologists ... [to] share experiences and formulate guidelines . . . 4. Istablish an Advisory Panel to such an Interagency Committec, composed of recognized psychologists from outside government to periodically review agency assessment procedures and programs and to assist the Interagency Committee in its activities. 5. Establish a Task Force under contract with the National Academy of SciencesNational Research Council . . . to survey and evaluate current agency assessment procedures and practices and to make recommendations." Id. at 147-48.

${ }^{178}$ of course, it might be concluded that the validity and reliability of psychological tests are such that they should be abandoned completely by the Government. See part II $\mathrm{F}$ of this article.

170351 U.S. 536 (1956).

${ }^{180}$ See note 32 supra and accompanying text. 
relationship, a government employee's rights are inferior to those of any other citizen. Congressional hearings on testing have pointed the way to solutions. They have, from all indications, also initiated a much-needed dialogue between lawyers and others concerned with individual rights and the scientists, technicians, and professional medical men responsible for the new scientific instruments and devices. In the private sector, observance of the individual's rights will depend to a very great extent upon the intensity and continuity of that debate. However, insofar as a citizen's relations with his Government are concerned, Congress has it within its power to insure that individual rights and liberties are not seconded to technology. 